\title{
Village Funds Management; Description of Murung Uut Performance, Murung Raya District
}

Indra Wijaya, Jamal Uddin, Setia Budhi

Master Program of Government Science, Lambung Mangkurat University, Banjarmasin, Indonesia

DOI: $10.36348 /$ sjef.2020.v04i06.005 $\quad$ | Received: 30.05 .2020 | Accepted: 07.06.2020 | Published: 12.06 .2020

*Corresponding author: Indra Wijaya

\section{Abstract}

This study aims to analyze the performance of Village Fund Management in the Uut Murung District, Murung Raya Regency. In this study, researchers focused on the performance of village officials. The research uses a qualitative approach, with methods descriptive. Performed three data collection techniques, namely; observations, interviews, and documentation. The analysis used Miles and interactive modelsHuberman, among others; data reduction, data presentation, withdrawal conclusion, and data verification. Research result describes; five dimensions examined, 4 (four) dimensions did not function properly such as the dimensions of responsibility, service quality, productivity, and accountability while the dimensions responsiveness works pretty well. Based on these findings it is recommended improvements such as training or courses for village officials and the provision of media as a tool to account for the management of village funds so performance Uut Murung Subdistrict government, Murung Raya Regency is expected to be more optimal than before.

Keywords: Accountability, Service Quality, Responsibility.

Copyright @ 2020: This is an open-access article distributed under the terms of the Creative Commons Attribution license which permits unrestricted use, distribution, and reproduction in any medium for non-commercial use (NonCommercial, or CC-BY-NC) provided the original author and source are credited.

\section{Preliminary}

Institutions that are autonomous with their traditions, customs, and laws that is deeply rooted and relatively independent of intervention outside power [1]. Various analyzes and ideas then pushed the Government to enact Law No. 6 years 2014 on Villages, is expected to elevate the village to the position of an honorable subject in national and state life, because it will determine the right village format following the context of local diversity, as well as an instrument to build a vision towards a new village life that is independent, democratic and prosperous. This law provides an opportunity for villages and weapons for village people to launch change. The village will be worth as place as life and livelihood, be Foundation important for the progress of the nation and state in the future $[2,3]$.

Several authorities possessed by the Village, among others are local-scale village authorities and the authority of original rights. Thus to exercise this authority, the village needs to formulate village planning that involves all components of the village community [4]. A good planning process will give birth to good program implementation, and in turn, will foster community participation to be involved in village development. The process of planning, implementing, and evaluating village development activities themselves is a tangible manifestation of the authority to manage and manage village development on a local village scale [5].

Village development is one thing that is fundamental to the existence of the Law in this village is also related to village funds which are considered very sensitive in its management [1]. With the regulation, this brought new hope to the village community to build their respective villages. The mandate of law village invitation requires villages to manage their finances based on the principles of transparency, participation, and accountability. This also certainly affects physical development, namely the development of the village infrastructure itself.

The magnitude of the village fund budget in existing villages certainly leads to demands for more effective management, especially related to village infrastructure development as regulated through Regulation of the Minister of Villages, Development of Disadvantaged Regions, and Transmigration Number 4 of 2017 concerning changes Permendes Number 22 of 2016 concerning Determination of Priority for Use of 
Funds Village of the Year 2017. Effective village fund management should also look at village infrastructure that is increasingly developing, especially related to physical facilities [6].

But in managing village funds there are always problems. As it was explained that the current condition of the regional government apparatus is still low, especially in the case of regional financial management. human villages are the main obstacle [5]. The capacity of human resources in the village has been uneven. The Ministry of Finance also assesses that village officials are not ready to accept the current village budget. There are problems with the administrative and governance capacity of village government officials that are still minimal. The accountability system and monitoring institutions are still weak, including the community's lack of criticism over the management of village revenue and expenditure budgets.

Concerning the village fund, the Sub-District is a district apparatus as a regional technical implementer that has a specific work area and is led by the Camat, as mandated in Government Regulation Number 43 of 2014 Article 101 and Permendagri Number 113 of 2014 Article 23, the regent may delegate the evaluation draft village regulations concerning APB Desa To the District Head, besides, the District Head has a role in the delivery of the Realization Report APBDes and Implementation Realization Accountability Report APB Desato the regent, then in the management of village funds is also the responsibility of the District. One direction and fostered by the District in managing village funds is to conduct directions and fostered for the utilization of village funds.

Uut Murung Subdistrict as one of the subdistricts in Murung Raya Regency is a sub-district with the widest scope of work, where the area is $7,263 \mathrm{~m} 2$ or $30.65 \%$ of the total area of Murung Raya Regency, and its location which has a considerable distance where the distance of the capital of Uut Murung District, Tumbang Along to the capital of Murung Raya Regency is $114 \mathrm{~km}$. This condition makes the Uut Murung Subdistrict Office have an upper center government and has high demands related to performance because it is the spearhead of government in the Uut Murung District. The condition of Uut Murung Subdistrict, the vast Murung Raya Regency has an impact on the running of the government because there are villages that do not have transportation access. This challenge demands high performance from Uut Murung Subdistrict in coaching and monitoring the management of existing village funds.

\section{RESEARCH METHODS}

The approach that will be used in this research is qualitative because the researcher intends to obtain an in-depth description of the performance of the Uut
Murung Subdistrict in the management of the Village Fund. A qualitative approach is a process of research and understanding based on the methodology that investigates a social phenomenon and human problems [7]. In this approach, the researcher makes a complex picture, examines words, detailed reports from the respondents' views, and conducts studies in natural situations. This research is included in the type of descriptive qualitative research which is intended to study intensively about the background of the problem situation and the position of an event that is currently taking place, and certain specific social unit environmental interactions that are (given) [8]. Data collection techniques are as follows: 1) Observation, conducted to observe carefully and thoroughly the actual situation in the field and observe the symptoms that exist and arise to be used as research material, 2) In-depth interviews to obtain primary data in this study, so that they can achieve research objectives, 3) Documentation, recording the form of information either documents or records, studying books, papers, regulations, research journals and other written materials related to research topics related to research issues, but also to support This data collection is by the camera to get data in the form of image visualization [9].

The technique used in this study is a qualitative analysis technique according to Miles and Huberman in Sugiyono [7];

1. Data reduction, which is the process of selecting, focusing on simplifying the extraction and transformation of raw or rough data that appears in written records in the field. Data reduction is done by making a summary, developing the system the coding, browse themes, create clusters, and write memos.

2. Presentation of data, which is the process of compiling complex information in a systematic form so that it becomes more simple and selective, and its meaning can be understood. The presentation of data is intended to determine meaningful patterns, as well as provide the possibility of drawing conclusions and taking action. After the data has been reduced the researcher presents the data so that the data about this research can be organized, arranged in a relationship pattern so that it is more easily understood.

3. Draw conclusions, namely the analysis is carried out continuously both during and after data collection to draw conclusions that can illustrate a pattern of events that occur. Researchers can make loose and open conclusions that at first were unclear and then increased to become more detailed and firmly rooted. Conclusions are formulated after the last data collection, depending on the field notes, the coding, data storage, and retrieval methods used. Conclusions are drawn based on matrices made to find patterns 
following research [10].

\section{RESULTS AND DISCUSSION}

Village Funds are funds sourced from the State Budget which are used to finance government administration, development implementation, community development, and community empowerment. The granting of Village Funds to villages is also accompanied by the obligation to implement them accountable to realize the implementation of regional autonomy in line with efforts to create good governance up to the village level [11]. Accountability is not only related to financial problems contained in the APBDesa with the Village Fund as one component in it but also the entire set of policies and activities in the management of the Village Fund from planning to accountability [12].

The District Government of Uut Murung, Murung Raya Regency as an institution in carrying out its mission to achieve the goals set must be through means in the form of an organization driven by a group of people who play an active role as actors, in this case, employees in the organization. The achievement of organizational goals is only made possible by the efforts of employees who are in the Uut Murung District Government of Murung Raya Regency. In this case, there is a close relationship between employee performance with organizational performance, or in other words, if employee performance is good then organizational performance is good [13]. Inperspective accountability, the form of performance of Uut Murung Subdistrict Murung Raya Regency is described as follows:

\section{Legal Accountability and Honesty}

Indicators of legal accountability and honesty are assessed from the aspect of compliance with procedures. Indicators of compliance with procedures related to compliance and suitability of Village Fund management procedures by the village government based on applicable regulations. Accountability in the management of Village Funds in Uut Murung Subdistrict, Murung Raya Regency in 2018 based on this indicator is a form of accountability regarding the compliance and suitability of the procedures for implementing and managing Village Funds against applicable laws and regulations.

Based on the results of the study, the management of Village Funds in 2018 by the Uut Murung Subdistrict Murung Raya District began with the preparation and stipulation of RKPDesa and APBDesa which were part of the planning stage in the management of Village Funds which became an integral part of village finance. This is following Article 20 (1) Regulation of the Minister of Home Affairs Number 113 of 2014 concerning Guidelines for Village Financial Management which states that in planning the village secretary prepares a draft village regulation on APBDesa based on the RKPDesa of the relevant year.

After planning, the government of Uut Murung Subdistrict, Murung Raya Regency implements programs and activities of the Village Fund that have been determined as manifestations of Articles 24 to 34 of the Minister of Home Affairs Regulation No. 113 of 2014 concerning Guidelines for Village Financial Management and Articles 23 to 32 of Murung Raya Regent's Regulation Number 12 of the Year 2015 concerning Guidelines for Village Financial Management. During the implementation of the programs and activities of the Uut Murung Subdistrict government also recorded and collected administrative completeness which is a form of administration following Article 35 (2) Regulation of the Minister of Home Affairs Number 113 of 2014 concerning Guidelines for Village Financial Management which states that the Village Treasurer is obliged to record every receipt and expenses and close the books at the end of every month in an orderly manner.

The results of administration will then be used as material for the preparation of reports to the government of Murung Raya Regency and other relevant stakeholders as a form of reporting following article 8 (1) of Murung Raya Regent Regulation Number 3 of 2018 concerning Procedures for Calculating and Distributing Details of Village Funds for Each Village in Murung Tahun Regency Budget 2018 which states that the village head coordinated by the local sub-district head reports on the realization of the use of the Village Fund phase I, phase II and an annual report on the use of the Village Fund to the Regent. Other than that, accountability is also carried out to the community and related stakeholders following the Regulations of Murung Raya Regent No. 8 of 2016 concerning Village Financial Management Guidelines which mandate that the APBDesa accountability report and the accountability report be informed to the public in writing and with information media that is easily accessible by the community. The whole series of stages starting from planning, implementation, administration, reporting, and accountability are the efforts of the Uut Murung District government to realize accountability in the management of the Village Fund. That is because the accountability of government financial management is the responsibility regarding integrity, disclosure, and obedience to the laws and regulations [14].

\section{Program Accountability}

An indicator of the results of the program being implemented is related to statement achievement of the results of the implementation of the program whose source of funding comes from the Village Fund [15]. The accountability of the management of the Village Fund in Uut Murung in 2018 based on this is the responsibility of the Uut Murung sub-district 
government to answer and explain the results of the implementation of programs and activities to those who have the right or authority to request information or accountability. Based on the results of the study, the Village Fund in Uut Murung sub-district in 2018 which $91 \%$ was devoted to the development sector could achieve output realization of $100 \%$ following the RKPDesa and APBDesa in 2018 Uut Murung subdistrict in the form of 18 programs and development activities carried out, resulting in 18 physical building units new and 1 physical building rehabilitation results that can be seen, felt and used by the community directly. The physical output is following the Regulation of the Minister of Villages, Disadvantaged Regions, and Transmigration Number 21 of 2015 concerning Determination of Priority for the Use of Village Funds in 2016 Article 6 (1) and Regulations of the Murung Raya Regent Number 7 of 2016 concerning Procedures for Calculation and Distribution of Village Fund Details Every Village in Murung Raya Regency 2016 Fiscal Year Article 6 (1) which mandates that the Village Funds in the development sector are used, inter alia, for development, development and maintenance infrastructure or physical facilities and infrastructure in the field of livelihoods (food security and settlement), public health, education, social and culture, the infrastructure of production and distribution (community economy) and/or renewable energy infrastructure and environmental preservation activities.

On the other hand, $9 \%$ of the Empowerment Fund in 2018 is used to empower Uut Murung subdistrict government apparatus to produce physical output in the form of RKPDesa and APBDesa which is a routine document that must be compiled by the Uut Murung sub-district government annually, potential data, monographs, and village population and apparatus wifi installed in the village office. Output in the form of potential, monographic and village population data is still in the form questionnaire rough data that has not been processed into complete data in the form of village profile documents and monographs following the output planned in the RKPDesa and the output in the form of wifi devices is only limited to use by village officials during working hours, cannot be utilized by the community. Meanwhile, the non-physical output in the field of empowerment of the Village Fund cannot be explained with certainty by the Head of Government Section who holds the task and responsibility for the implementation of the Village Fund empowerment field in Uut Murung Subdistrict in 2018. This is because the activities carried out are still of a socialization nature and no follow-up has been carried out by the subdistrict government so that only generates knowledge.

Physical and non-physical outputs of Village Funds in the field of empowerment generated, in addition to not being able to reach the specified outputs, in reality, are also not following the Regulation of the Minister of Villages, Development of Disadvantaged
Regions, and Transmigration Number 21 of 2015 concerning Determination of Priority in the Use of Village Funds in 2016 Article 8 and Regulation of the Murung Raya Regent Number 7 of 2016 concerning Procedures for Calculation and Distribution of Details of Village Funds for Each Village in Murung Raya Regency 2016 Budget Year Article 6 (2). Both of this rules mandate that the Village Fund used in the field of empowerment should be used to (1) increase village economic investment, (2) support for economic activities developed by BUMDes or BUMDes Together, as well as other village community economic groups, (3) capacity building programs and village food security activities, (4) community organizing, facilitation and training for village communities and legal assistance, (5) promotion and education of public health, (6) support village/community forest/beach management activities, (7) increasing the capacity of community groups for renewable energy and environmental preservation, and/or (8) other economic empowerment activities that have been determined in village deliberations.

\section{Obstacles to Village Fund Management Performance}

The management and implementation of village financial programs or activities are certainly found to be problems and factors which hamper their performance [23]. This shows that the management of the Village Fund as part of village finance also has problems and factors that hamper its performance. Village Fund Management in 2018 by the Uut Murung sub-district government shows that there are factors that hamper the performance of village officials. The inhibiting factors of the 2016 Village Fund management performance include:

\section{The rules}

The rule becomes one of the factors creating a performance that has considerable influence. This is because rules are guidelines or guidelines that are necessary so that the organization, work, and officers have a legal basis and can walk or work regularly and directed. Government regulations at the district level, especially district regulations that were late issued and changed, resulted in the management of Village Funds in 2018 in the Uut Murung sub-district starting from the planning, implementation to reporting, and accountability levels of Village Fund management. This is according to Muradi and Rusli [16] because the rules generally emphasize SOPs that have been set regularly and systematically to provide guidance and encouragement in the implementation of work. Rules are also explicit statements about what should or should not be done [12]. Both of them stated that the rules are binding to give vigilance to the implementation of the work so as not to deviate and get sanctions. Therefore, regulations that is late to be issued, change and is less specific result in the absence of a legal basis and guidelines for the implementation of Village Fund 
management, so that the village government becomes confused and very careful in implementing Village Fund management, and chooses to wait for regulations to adjust it. Both of them stated that the rules are binding to give vigilance to the implementation of the work so as not to deviate and get sanctions.

Regulations that are late to issue, change, and are less specific are also related to political conditions which are the external factors determining success or failure of policy implementation according to Van Meter and Van Horn. That is because the Village Fund management regulations set by the Murung Raya Regent through the Regent's regulations are policies issued by political officials. The political policy also shows the commitment and interests that are fought for and wanted to achieve by public officials [11]. Therefore, the late issuance, changeable, and less specific regulation of Village Fund management shows that the commitment of the Murung Raya Regency Government to achieve the Village Fund's goal of increasing well-being rural communities and the quality of human life and poverty reduction is less than the maximum.

\section{Work structure arrangement}

Work arrangements and mechanisms must produce accountability [15]. This shows that the regulation of work structure is one of the factors that can influence the creation of accountability. Based on the results of the study, the work structure of the Uut Murung sub-district government did not consider the competency or knowledge of government factors but paid more attention to the seniority factor which led to the ineffective implementation of the Uut Murung subdistrict government. The work structure itself is the way the organization organizes resource human for activities toward goals, as well as harmonious ways of placing humans as part of an organization in a relatively fixed relationship that largely determines patterns of interaction, coordination and task-oriented behavior [6].

A really good organizational structure and work structure does not exist, but to get it, one must pay attention to the specialization of activities, the standardization of activities, the coordination of activities, the centralization and decentralization of decision making, so that employee performance will be well implemented, where each employee will know what must be done, reported and accounted for [14]. Therefore the organization must be able to place the right people who have the talents and abilities following the work they do so that the performance results obtained can be maximized.

The attitude and policy of the Village Head in Uut Murung Sub-district in the work structure arrangement show that the Village Head is unable to place the right people who have the ability following the work they are doing in the organizational structure and work procedures of the village government. A stable village government organizational environment should be suitable and manageable with a mechanical organizational structure that is closely related to the Weberian bureaucratic structure proposed by Max Weber [17].

\section{Resource human apparatus}

Resource humans are the potential contained in human beings to realize their role as adaptive and transformative social beings who can manage themselves and all their potential to achieve well-being [18]. Resource competent and quality human beings are needed to support productivity and activities so that organizational goals can be achieved.

Based on research, resource village government officials in the Uut Murung sub-district lack understanding of their role in village governance, lack skills in operating computer equipment, and entering old age. These conditions indicateresourceVillage the government human apparatus is not yet qualified and has competence. That is because resource quality human beings are those who can exercise the authority and responsibilities given to them [5]. While resource competent humans are those who have the ability to achieve the organization that must be possessed for the organization both short and long term that is needed to deal with rapid environmental changes [19].

The vital position of human resources in the organization, also applies to village government organizations, where resource competent and qualified human resources are needed to support productivity and activities so that village government goals can be achieved, one of which is the management of village finances and the Village Fund. The same thing applies to vice versa, where resource human beings who are incompetent and qualified to hamper productivity and achievement of village government goals. Hampering the achievement of village government goals is an indication that accountability for Village Fund management has not been realized. That is because the achievement of objectives is one indicator of accountability.

\section{Facilities and infrastructure}

Competent and quality human resources will work more optimally and support productivity and activities so that organizational goals can be achieved if equipped with work facilities such as facilities and infrastructure. Facilities and infrastructure are facilities that support the smooth implementation of work to achieve conformity to requirements including buildings, workspaces, and suitable facilities, process equipment (software and hardware), and support services [3]. Based on the results of the study, the village government in Uut Murung sub-district only had 1 set of desk computer equipment and two laptops that were 
used in rotation between the village treasurer, the head of the government section, and the head of the development section.

Village Fund Management in 2018 by the village government in the Uut Murung subdistrict externally is also hampered because the Village Financial System or Siskeudes has not been formed and implemented online by the Murung Raya Regency government. These conditions indicate that the village government experiences limited infrastructure in managing Village Funds in 2016. Based on the Regulation of the Minister of Home Affairs No. 7 of 2006 concerning Standardization of Facilities and Infrastructure of Local Governments, work infrastructure is a facility that indirectly functions to support the implementation of an apparatus work process in improving performance following the tasks and its responsibilities.

\section{Work and Community Culture}

The essence of accountability is about providing information between two parties; of which one is the one to be responsible provide an explanation or justification for other parties who have rights to responsible mentioned [17]. This also applies to the accountability of village financial management and Village Funds by the village government, especially accountability to the community. Based on the results of the study, the village government in Uut Murung sub-district besides working not yet based on data, the accountability carried out also experienced obstacles related to the culture of the village community which still tended to be passive and put high trust in the village government in the management of the Village Fund in 2018.

As Gray et al. [20], if the party who has the right to accountability, namely the village community is passive and tends to put high trust in the village government so that the oversight and supervision of the management of the Village Fund are neglected, then the essence of accountability will not be realized [2, 21]. The same case occurred in Muara Pari Village, Lahei Sub-district, North Barito Regency based on the results of Syamsiah research [22], accountability of village financial management, especially $\mathrm{ADD}$, was hampered due to the lack of community responsiveness to report information implementation villages and the lack of oversight of village government responsibilities.

\section{CONCLUSION}

The Conformity of the Implementation of Village Fund Management for Infrastructure Development with Applicable Regulations. Village Fund Management in infrastructure development in Uut Murung Subdistrict in 2018 has a match between planning and budget realization for infrastructure development. While in terms of the timing of the implementation of infrastructure development with the realization time of the completion is following the planned time of the implementation of infrastructure development. But in the implementation document only limited the time needed to complete the infrastructure development program, there is no detail when the implementation time.

Transparency in Village Fund Management by the Village Government in the Uut Murung sub-district in 2018 can be concluded to be inadequate. This can be seen from:

1) Planning that involves the community; the Village Government tends to only involve the community who always agree with the policies determined by the village government. Whereas people who think about the sustainability of Village Fund management so that it is right on target (critical), are not be involved in Musrenbang.

2) The implementation of infrastructure development in the Uut Murung sub-district in 2018 always involves the community in terms of physical and financial involvement. Then every implementation of the activity in respectively- each infrastructure development project, is informed through information boards provided by each hamlet and each the object implementation of infrastructure development activities.

3) The forms of evaluation that involve the community in the transparency of Village Fund management include Community complaints that convey the difference in the amount of the budget between the appropriate amount of the budget in the market and the realization. Then in the submission of the Village Information System (SID) village website that is still not good. That is due to inadequate human resources to carry out this task and there must be assistance to the management of the village website so that it can submit the form of village reports not only in the infrastructure development program but in the overall work program of the Uut Murung subdistrict Government's activities so that the government can achieve transparency and accountability.

4) Community participation in managing village funds has not been maximized. The two models of community participation that emerged were pure and pseudo. Pure participation is community involvement in analyzing the form of reports on the implementation of activities, and community participation in the implementation of activities to carry out community self-help. The apparent participation associated with the coordination meeting held by the Village Government of the Uut Murung sub-district did not involve the community who were active in criticizing the government's performance, but only those who were in favor of the village government to implement the program. 


\section{REFFERENCE}

1. Santoso, P. (2003). Pembaharuan Desa Secara Partisipatif. Yogyakarta: Pustaka Pelajar.

2. Budiman, A. (1995). Teori Pembangunan Dunia Ketiga. Jakarta: Gramedia Pustaka Utama.

3. Dwiyanto, A. (2008). Reformasi Birokrasi Publik Indonesia. Yogyakarta: Gadjah Mada University Press.

4. Arif, M. (2007). Tata Cara Pengelolaan Keuangan Desa Dan. Pengelolaan Kekayaan Desa. Pekanbaru: ReD Post Press.

5. Ismail, M., Widagdo, A. K., \& Widodo, A. (2016). Sistem Akuntansi Pengelolaan Dana Desa. Jurnal Ekonomi dan Bisnis.

6. Utami, E. T. (2007). Peranan Badan Permusyawaratan Desa dalam Perencanaan Pembangunan Desa. Medan: Universitas Sumatera Utara.

7. Sugiyono. (2008). Memahami Penelitian Kualitatif. Bandung: Penerbit Alfabeta.

8. Moleong, L. J. (2002). Metode Penelitian Kualitatif. Bandung: PT Remaja Rosdakarya.

9. Gunawan, I. (2014). Metode Penelitian Kualitatif Teori dan Praktik. Jakarta: Bumi Aksara.

10. Saebani, A. D. (2009). Metodologi Penelitian Kualitatif. Pustaka Setia: Bandung.

11. Keban, Y. T. (1995). Indikator Kinerja Pemerintah Daerah: Pendekatan Manajemen dan Kebijakan. Yogyakarta: Fisipol UGM.

12. Nurcholis, H. (2011). Pertumbuhan dan Penyelenggaraan Pemerintahan Desa. Jakarta: Penerbit Erlangga.

13. Ruky, A. (2001). Sistem Manajemen Kinerja.
Jakarta: PT. Gramedia Penerbit Utama.

14. Syukri, M. (2015). Peran Kecamatan dalam Pelaksanaan Undang-Undang Desa. Jakarta: The SMERU Research Institute.

15. Surjadi. (2009). Pengembangan Kinerja Pelayanan Publik. Bandung: Refika Aditama.

16. Rusli, Z. Akuntabilitas pelayanan publik. Jurnal Administrasi Pembangunan, 1(2), 189-196.

17. Tika, M. P. (2006). Budaya Organisasi dan Peningkatan Kinerja Perusahaan. Jakarta: PT. Bumi Aksara.

18. Hasiani, V. V., Ahmad, I., \& Rijai, L. (2015). Isolasi jamur endofit dan produksi metabolit sekunder antioksidan dari daun pacar (Lawsonia inermis L.). Jurnal Sains dan Kesehatan, 1(4), 146153.

19. Prabu, A. M. (2003). Evaluasi Kinerja SDM. Bandung: PT. Refika Aditama.

20. Gray, T. J. (1997). U.S. Patent Application No. 29/061,898.

21. Nyoman, I. S. (2005). Perencanaan Pembangunan Daerah Otonom dan Pemberdayaan Masyarakat. Jakarta: Citra Utama.

22. Habibu, R., Syamsiah, M., Hamiruce, M. M., \& Iqbal, S. M. (2012, September). UPM-3D facial expression recognition Database (UPM-3DFE). In Pacific Rim International Conference on Artificial Intelligence (pp. 470-479). Springer, Berlin, Heidelberg.

23. Rivai, V. (2005). Manajemen Sumber Daya Manusia Untuk Perusahaan dari Teori ke Praktik. Jakarta: PT. Rajagrafindo Persada. 